\title{
Development and Validation of Module for Teaching Human Rights at Higher
}

\section{Education Level}

* Haroon Ur Rashid, PhD Scholar (Corresponding Author)

** Ashfaque Ahmad Shah, PhD, Assistant Professor

*** Dr. Muhammad Sarwar, Professor

\begin{abstract}
The study focused on the development and validation of modules for teaching Human Rights (HRs). The researchers developed modules consisted of nine units, based on previous modules and literature. One group pre-test-post-test (pre-experimental) design was used to validate the module. A Selfreported 5-point Likert scale (22-item) was developed for pre- and post-test assessment. Forty-seven (47) final year students of BS education were pre-tested, 27 hours treatment was given to them through the teaching of Human Rights Values (HRVs) by using Modular Approach (MA), and again tested. Data were analyzed by applying a paired sample t-test. A significant difference was found in students' attitudes towards learning HRs before and after the treatment. The mean gain score of the learners was higher on the post-test as compared to that of on pre-test. Hence, it is concluded that the module for teaching HRs has been proved to be valid and effective. Higher Education Commission (HEC) of Pakistan may recommend a separate course on Human Rights Education (HRE) at BS level, based on MA. Special training to use this module and the assessment tool to university teachers may be arranged by either the local authorities at the universities or the National Academy of Higher Education (NAHE) by HEC Islamabad-Pakistan.
\end{abstract}

Keywords: Teaching Module, Human Rights, Human Rights Education, Teaching of Human Rights, Introduction Higher Education

Education performs a significant part in the progress of a country. To develop success at international, national, and regional levels, education is regarded as one of the main contributors. Human rights education (HRE) fosters awareness regarding human rights (HRs). It also promotes a method of knowledge sharing among parents, students, and the society in general, to extend competences in persons to realize and prevent human rights' infringements. A quality education, rooted with ideas and values of HRs, can make children responsible citizens and can foster human rights.

Human rights are a total of all the essential rights that each person deserves only due to human being as a necessity of human respect exclusive of any distinction. Such rights are qualitatively inalienable and inviolable, related to personality. These can't be arbitrarily removed and delimited by a state or another authority and they can't be transferred to others by the individuals themselves, they can't give up them (Yeşil, 2002).

Implementation and protection of human rights essentially rely upon HRE. Human Rights Education confirms that human beings are made informed of their rights, learn to apply, and enhance the rights as much as possible, and it makes them aware that others hold their rights too (Gülmez, 2001).

Human Rights Education's universal domination started in the mid-1990s to onward. To foster social unity worldwide, HRE holding the highest significance. In several countries, it is an integral segment of a formal system of education. As it is obvious that peace in a society can't be guaranteed without HRE. The fundamental goal of HRE is to make people responsible citizens and to teach them according to the law regarding their rights (Nordin, Shapiee, Suhor, \& Muhamad, 2012).

According to Nordin et al. (2012), the roots of Human Rights Education were commenced from the United Nations (UN) Decade for HRE (1995 - 2004), declared in General Assembly's

\footnotetext{
* Department of Education, University of Sargodha Email: haroonurrashid129@ gmail.com

** Department of Education, University of Sargodha Email: multanxa@ gmail.com

*** Department of Education, University of Sargodha Email: drsarwar@ymail.com
} 
December 1994 Resolution 49/ 184. The Plan of Action of the UN Decade for HRE stressed that the states must construct different particular approaches and programs which distribute public information by emphasizing, encouraging, and promoting the HRE activities for making certain the comprehensive education of human rights.

In the same way, HRE is a salient feature of the educational program proposed by UNESCO, under the notion of "Learning to Live Together", which emphasizes the promotion of cultures, values, beliefs, respect for others, consideration, and understanding which eventually produce the peaceful existence, non-violence resolution and conflict avoidance (Tibbits, 2006).

It has been recognized in national education policy 2009, that HRE is to be infused in the curriculum, and in this context awareness and training materials are to be developed for teachers and students, taking into account understandings and cultural values (Government of Pakistan, 2009). The stress was given on promoting the notion of universal brotherhood and Muslim Ummah through textbooks and curriculum in national education policy 2017. It has also been addressed that the golden principles of human rights, tolerance, and peace, etc. will be lime lighted in teacher training and curriculum and Islamic learnings will be disseminated to the entire world (Government of Pakistan, 2017).

The Constitution of Pakistan 1973 promises equal rights to all citizens, rejects discrimination based on merely gender, and supports steps to assure women's full contribution in each domain of life. Constitution's first chapter gives the list of twenty-eight fundamental rights and their explanation, for example, freedom to allow religion, freedom of speech, equality of citizens, right to education, which are protected in the constitution (Government of Pakistan, 2012).

\section{Statement of the Problem}

Human rights lead to the peaceful co-existence of citizens which further leads to the prosperity of society and country. Although the religion of the majority and constitution of Pakistan (Government of Pakistan, 2012) protects human rights, nevertheless, human rights' status is not up to the mark incountry (Ali, 2000).

Almost all policies have emphasized the human rights and representation of 'human rights' is there in the curriculum also. But this representation is in a scattered form, which is not bringing the desired results. Major international reports such as Human Rights Watch, (2019), Amnesty International, (2019), and the Human Rights Commission of Pakistan, (2019) portray the deteriorating condition of human rights in Pakistan.

The above-said state of affairs demands a focused approach for teaching human rights, which may inculcate human rights in students in a more effective way. A modular approach (MA) improves the effectiveness (by reducing the gap between what we intend to teach and what is taught). Modular Approach (MA) is being commonly used to design courses of programs/workshops for human resource development, capacity building, and training programs for teachers, and higher education. Various initiatives of recent reforms are concerned about shifting the emphasis of classroom situations from instructor to the learner (Mizrachi, 2010). Module is the best option that can be employed in the classroom as a learning material for learner-cantered learning and teaching. Studies regarding the teaching of human rights are rare. There is no study available in Pakistan (Iqbal, 2005). So, the present study intends to develop and validate a module for teaching human rights at higher education level in Pakistan.

It was hypothesized that there is an insignificant difference in students' attitudes towards learning human rights values before and after the treatment.

\section{Literature Review}

The literature review shows rigorous research on the Modular Approach (MA) at international and national levels. The investigation carried out regarding MA has recognized the following fundamental principles and advantages of this method of instruction.

Module is a self-instructional, self-contained package that allows the student to continue his studies according to his skills and capacities. It might be employed in each social background appropriate for the student. The researchers and educational scholars of the developing, as well as developed countries throughout the globe, have been identified module as the most effective and beneficial resource of learning. It is a sort of special learning source. The module covered the content of a certain subject matter or a set of contents. To make the procedure of learning dynamic and alive, it confirms the active involvement of learners (Ali, 2005). The content of the module is divided into 
small phases or tasks of learning. Each phase has well-defined objectives, experiences of learning, evaluation, and feedback. Modules are interest provoking and self-motivating, with the full participation of students. In modular instruction, the teacher works as a facilitator (Shaheen, 2013). Sejpal (2013) defined module as a working unit in an instructional course which is essentially selfsufficient and teaching method which is based upon strengthening the knowledge and abilities in distinct units.

Laroza (2015) researched to establish the efficiency and validity of constructed modules in the subject of "Social Orientation" or "Personality Development and Public Relations" (PDPR) at the university level in 2009-10. Respondents of the study were 30 students of the second year and 15 professors of PDPR. The method of study was descriptive-experimental. Test results and questionnaire-checklist was employed as a tool to gather data. The following criteria were used in the validation of modules by the professors of PDPR: objectives, subject material, presentation and organization, style and language, and effectiveness of the module. To establish the achievement of control and experimental group pre-post-test design was employed. Mean, Standard Deviation, and rank distribution were employed for data analysis. T-test was employed for measuring the significant variance in the mean score of the experimental and the control group as showed by the results of the post-test. Modules were found valid as instructional material. The experimental group's performance was high along with pre and post-test results. Modules were found highly effective as perceived by professors and students.

Ibyatova, Oparina, Rakova (2018) conducted a study to explore the modular approach's effectiveness in the teaching-learning process to assess motivation, achievement, and performance of learners and to determine either modular instruction is much effective than the conventional approach. An experiment was conducted with two groups of learners studying English at a technical university. For addressing modular learning, teaching, and evaluation's effect upon learners of engineering, quantitative and qualitative methods of research were combined. It was revealed from the experiment that learners of modular courses fond it motivating and useful and said that "it encourages them to do better on the next modules". Simultaneously, modular assessment and learning did not eliminate the workload and stress of conventional approaches. In the modular approach, teachers value the focus upon teaching requirements and the well-planned chance, about the exams. The structure and the approach of modules employed in the experiment still needs to develop and improve.

Barnes, Maye, Alfred, and Hayman (2000) researched to examine the function of modular instruction to motivate learners and they gained much through it. Overall, it shows that the group taught by the modular approach performs considerably higher than the group of the conventional approach of teaching. Motivation was improved related to the strength of the instructional method and the situation of short-range objectives. The Modularization encouraged positive change in the style of teaching as well.

Go Silk, Go Silk, and Somblingo (2017) researched to examine students' readiness of mathematics as well as to study whether the modular instruction is better than a conventional course about problem-solving of teaching mathematics concentrated metacognitive skills. "Static-groups pretest-post-test design" was used, with 146 and 144 students for the experimental and control group, respectively. To measure readiness "TIMSS-based mathematics test" was employed, whereas to measure the proficiency of problem-solving, a problem-solving test was employed. A middle level of math readiness was shown by both of the groups. Similarly, the experimental group indicated considerably greater proficiency in problem-solving than the control group. So, the experimental group presented higher metacognitive proficiencies.

Ali, Ghazi, Khan, Hussain, and Faitma (2010) examined the impact of modular instruction on the achievement of the learners. They employed the experimental method. The study design was an equivalent group. Mean, Standard Deviation, and t-test were employed for the analysis and interpretation of the collected data. Research findings supported the modular approach. It was concluded that overall, modular instruction is much effective than the traditional teaching method as a process of teaching and learning for biology. Since in modular instruction the learners are offered the chance to study according to their needs, ability level, and pace. In this self-study mode, instant reinforcement is offered as feedback for the motivation of the learner to practice a task. The study recommended this approach to be used widely in traditional classrooms at different educational levels. 
Khatoon (2004) carried out a study to investigate the level of difference in moral sense improvement of secondary school students. There was a considerable difference between moral sense improvement of learners, learned by the conventional and modular instruction method. The method of modular instruction showed more supportive and showed many positive outcomes in the moral sense improvement of students as compared to the conventional method.

Sadiq and Zamir (2014) researched to explore the effectiveness of modular methods to examine achievement, performance, and learning of students as well as to establish that which is more effective either modular teaching or traditional methods. An equivalent group design was employed for experimentation. The sample consisted of thirty university students of "Master in educational planning and management". For analysis and interpretation of collected data from both controlled and experimental groups, Mean, Standard Deviation, and t-test were employed. The results supported the use of a modular approach. Modular instruction was found much use in teaching and learning processes than conventional methods of teaching. Because in modular instruction the students study according to their rate. It is an unrestricted mode of self-learning in which feedback and reinforcement are provided immediately to practice, which creates interest in the learners and motivate them. Modular instruction supports increasing the probability of learners to participate in the classroom to complete certain tasks immediately. Thus, the learner feels free to study as they desire.

Shaheen (2013) conducted an experimental research at the secondary level to establish the impact of modular approach integrated by ICT on learners' attainment and retaining in Biology. The experimental group was found better on retention, attainment, and post-test. The modular method was found similarly useful for low, moderate, and high achievers in the experimental group. Low achievers distinctively developed. Modular method confirmed as a whole extremely useful to enhance biology students' academic achievement and retention.

Behlol (2009) conducted a study in Pakistan at the secondary level to develop and validate the module in English. On post-test, a highly significant difference was observed between the control and the experimental groups mean scores. Considerable difference was also observed between mean gain scores of the control group and experimental group regarding high achievers. A highly significant difference was also observed between the mean scores of the control and experimental group regarding the low achievers. Thus, the material constructed as a module proved effective and valid from the learner' performance scores on the post-test.

Aalam (2019) carried out a study to explore the modular approach's effect on skills of English speaking in teacher's education. The module was developed and validated on English speaking skills. Several 50 prospective teachers of the Bachelor of Education program were the sample of the study. Pre-test-post-test experimental design was used. Independent sample t-test was used for data analysis. The module was found effective for the improvement of English-speaking skills. It was found equally effective for low to high ability students.

The above-mentioned studies conducted in this area at the international and national level, offered sound bases and attraction to the researcher for conducting this experimental research. The results of the current research will have considerable implications for teachers, students, curriculum developers, policymakers, instructional designers, and researchers for the planning of future research and actions.

\section{Methodology}

The teaching module was developed under the guidelines given by (PROAP, 1998) presented in "Learning to Live Together in Peace and Harmony: A UNESCO-APNIEVE Source Book for Teacher Education and Tertiary level Education" and with the help of previous modules and literature. It consisted of nine units. Nine lesson plans (truth, equality and justice, respect for human dignity, integrity, accountability, honesty, acceptance/appreciation of diversity, freedom and responsibility, and co-operation) were developed for this purpose - one for each unit. The duration of a lesson plan was 3 hours with a 20 minutes short break. The twenty-seven hours experiment was considered as 3 credit hours (three working hours per week). Module was discussed with the educational experts from the University of Sargodha to ensure its face and content validity. 


\section{Research Design}

An experiment was conducted to assess the validation and effectiveness of modules for teaching human rights. Different kinds of experimental research designs were being used in experimental studies such as; true experimental for comparison of two groups after manipulation, Solomon fourgroup design for comparison of four groups ( 2 control, 2 experimental), quasi-experimental for multiple experiments and pre-experimental for one group pre-test-post-test design (Creswell \& Clark, 2017; Gay et al., 2009). The current study was based on an experiment with one group. According to Gay et al. (2019), the one group pre-test-post-test (pre-experimental) design involves one group that is pre-tested, given to an intervention, and again tested. So, pre-experimental design was used in the present study.

\section{Subjects of the Experiment}

To validate the human rights teaching module, forty-seven (47) final year students of BS (session 2016-2020) from the Department of Education, University of Sargodha were taken as subjects of the experiment. The selection of the participants was made after seeking permission from the Chairman Department of Education.

\section{Research Tool}

A self-reported five-point Likert scale comprising 22 items was developed for students, based on activities included in the module for teaching human rights to its nine values (truth with 2 sub-values, equality, and justice with 2 sub-values, respect for human dignity with 5 sub-values, integrity with 2 sub-values, accountability with 2 sub-values, honesty with 1 sub value, acceptance/ appreciation of diversity with 3 sub-values, freedom and responsibility with 4 sub-values and co-operation with 1 sub value) for the collection of data for pre- and post-test assessment. This assessment tool was validated through experts' opinions.

To measure the internal consistency of the scales, Cronbach's alpha coefficient was calculated (Cronbach \& Meehl, 1951). The minimum recommended value of Cronbach's alpha is 0.7 as cut off for a reliable measure, which shows the degree of homogeneity among the items (Nunnally \& Bernstein, 1994). The reliability value of the scale as calculated through Cronbach's alpha was found to be 0.91 .

\section{Procedure of the Experiment}

The pre-test was conducted from the subjects of the experiment about the attitude towards learning human rights values before treatment. A twenty-seven hours treatment was given to the participants. Nine lesson plans were developed for this purpose - one for each unit. The duration of a lesson plan was 3 hours with a 20 minutes short break. The twenty-seven hours experiment was considered as 3 credit hours (three working hours per week). The experiment lasted for 9 weeks.

Participants were taught through a modular approach. Each session consisted of three segments, the beginning segment, a short break, and the concluding segment. The beginning segment involved an ice-breaking activity, orientation of topic, and the execution of the main activity. This segment lasted for one and a half hours. At the end of the beginning segment, the students were allowed to have 20 minutes break for refreshment. The concluding segment included discussion on the activity carried out in the beginning segment, students' feedback, and evaluation of students' attitude. At the end of the treatment, a post-test was conducted among the participants of the study about their attitude towards learning human rights values.

\section{Data Collection}

The researcher personally collected data with the help of a self-reported five-point Likert scale before and after the experiment. Data through the pre-test were collected with the intent to see to what extent participants of the study have a favourable attitude towards the Human Rights Values (HRVs). The purpose of the collecting data in the post-test was to validate the effectiveness of the module as to how it was succeeded in bringing about positive change in the attitudes of the learners.

\section{Results}

Data collected 'through pre-test and post-test before and after the treatment' from the subjects of the experiment were analyzed by applying inferential statistics (paired samples t-test) to assess the difference in students' attitudes towards learning Human Rights Values (HRVs). 
Table

Change in Human Rights Attitude of Students

\begin{tabular}{|c|c|c|c|c|c|c|}
\hline Human rights Values & Tests & Mean & D & SD & $\mathbf{t}$ & $\mathbf{P}$ \\
\hline 1. Truth & $\begin{array}{l}\text { Pre-test } \\
\text { Post-test }\end{array}$ & $\begin{array}{l}4.43 \\
4.81\end{array}$ & -0.38 & 0.81 & -3.25 & 0.00 \\
\hline 2. Equality and Justice & $\begin{array}{l}\text { Pre-test } \\
\text { Post-test }\end{array}$ & $\begin{array}{l}4.31 \\
4.57\end{array}$ & -0.27 & 0.66 & -2.77 & 0.01 \\
\hline 3. Respect for Human Dignity & $\begin{array}{l}\text { Pre-test } \\
\text { Post-test }\end{array}$ & $\begin{array}{l}4.14 \\
4.38\end{array}$ & -0.24 & 0.53 & -3.14 & 0.00 \\
\hline 4. Integrity & $\begin{array}{l}\text { Pre-test } \\
\text { Post-test }\end{array}$ & $\begin{array}{l}4.27 \\
4.66\end{array}$ & -0.39 & 0.71 & -3.82 & 0.00 \\
\hline 5. Accountability & $\begin{array}{l}\text { Pre-test } \\
\text { Post-test }\end{array}$ & $\begin{array}{l}3.74 \\
4.32\end{array}$ & -0.57 & 0.91 & -4.33 & 0.00 \\
\hline 6. Honesty & $\begin{array}{l}\text { Pre-test } \\
\text { Post-test }\end{array}$ & $\begin{array}{l}3.94 \\
4.32\end{array}$ & -0.38 & 1.03 & -2.54 & 0.01 \\
\hline 7. Acceptance/Appreciation of Diversity & $\begin{array}{l}\text { Pre-test } \\
\text { Post-test }\end{array}$ & $\begin{array}{l}3.99 \\
4.50\end{array}$ & -0.50 & 0.75 & -4.58 & 0.00 \\
\hline 8. Freedom and Responsibility & $\begin{array}{l}\text { Pre-test } \\
\text { Post-test }\end{array}$ & $\begin{array}{l}4.20 \\
4.70\end{array}$ & -0.50 & 0.77 & -4.44 & 0.00 \\
\hline 9. Co-operation & $\begin{array}{l}\text { Pre-test } \\
\text { Post-test }\end{array}$ & $\begin{array}{l}4.23 \\
4.64 \\
\end{array}$ & -0.40 & 0.92 & -3.00 & 0.00 \\
\hline Human Rights Attitude (Total) & $\begin{array}{l}\text { Pre-test } \\
\text { Post-test }\end{array}$ & $\begin{array}{l}4.14 \\
4.54\end{array}$ & -0.40 & 0.43 & -6.40 & 0.00 \\
\hline
\end{tabular}

$d f=46, D=$ Mean Difference $=$ Pre-test - Post-test

The table depicts the change in students' attitudes before and after the treatment. A paired samples t-test was applied to test the hypothesis. The results showed that the null hypothesis that 'there is an insignificant difference in students' attitude towards learning human rights values before and after the treatment', was failed to be accepted. A significant difference was measured in students' attitudes towards learning human rights values before and after the treatment. The mean value of the post-test was found higher than the mean value of the pre-test.

\section{Discussion}

A modular approach is taking much attention nowadays. It is a recent strategy to organize the learning experiences in classroom situations. It has become part of teaching at all levels. It is a selfinstructional package deals with a certain unit or subject material. It might be employed in a situation suitable for the student and can be accomplished according to the student's own pace. To apply modular instruction in classroom situations, appropriate practices and theories are exist.

The current study focused on the development and validation of a module for teaching human rights. So, the teaching module was developed under the guidelines given by PROAP (1998) in "Learning to Live Together in Peace and Harmony: A UNESCO- APNIEVE Source Book for Teacher Education and Tertiary level Education". It consisted of nine units (truth, equality and justice, respect for human dignity, integrity, accountability, honesty, acceptance/appreciation of diversity, freedom and responsibility and co-operation). The duration of each unit was about 3 hours with a 20 minutes short break, the total time of all units was 27 hours ( 3 hours per week for nine weeks). A significant difference was found in students' attitudes towards learning human rights before and after the treatment. So, it was concluded that the material designed in this study as a module of teaching human rights was proved valid and effective.

The findings of the present study are in line with the results of Barnes, Maye, Alfred, and Hayman (2000). They researched to examine the function of modular instruction to motivate learners and found that the group taught by modular approach performs considerably higher than the group of the conventional approach of teaching. Results of current research support the findings of Ali, Ghazi, Khan, Hussain, and Faitma (2010). They found a modular approach more useful to teach biology than the conventional lecture method. Since in modular instruction the learners are offered the chance to study according to their needs, ability level, and pace. Findings of the current research confirms the results of previous research carried out by Khatoon (2004), which inferred that modular approach was very helpful than conventional teaching method for the development of secondary school students' moral sense. Present research congruent with the research of Behlol (2009). He found a highly 
significant difference between the control and the experimental group's mean scores on the post-test. The experimental group achieved considerably higher than the control group. Thus, it verified the validity and efficiency of content utilized as a module. The findings of the current study are in line with the results of Shaheen (2013) which found the effectiveness of a modular approach to enhance biology students' academic achievement and retention. Findings of current research are in agreement with the findings of earlier studies which provided evidence of modular approach's effectiveness (Aalam, 2019; Ahmed, 2007; Ali, 2005; Ibyatova, Oparina, Rakova, 2018; Laroza, 2015). Moreover, the results are in line with the findings of some prior studies which provided evidence that the modular approach is better than conventional methods of teaching (Mizrachi, 2010; Sadiq and Zamir, 2014).

\section{Conclusions}

The teaching module was developed for nine human rights values (truth, equality and justice, respect for human dignity, integrity, accountability, honesty, acceptance/appreciation of diversity, freedom and responsibility and co-operation). It contained nine units (one unit for each value). The duration of each unit was about 3 hours with a short break of 20 minutes. The total time of all units was 27 hours i.e. 3 hours per week for nine weeks. The researcher conclusively has developed the module; which is now, along with its protocol, available to be used by the teachers and the researchers.

A significant difference was found in students' attitudes towards learning human rights before and after the treatment. So, it is concluded that the material designed in this study as a module of teaching human rights has been proved to be valid and effective.

\section{Recommendations}

Following recommendations are formulated based on the results of the research:

1. Higher Education Commission of Pakistan may recommend a separate course on Human Rights Education at BS level, based on a modular approach, and may provide training to university teachers for its teaching.

2. HEC may provide required academic and administrative assistance and adequate funding facilities to develop and validate the modules at higher education level outside/ within the institutes.

3. Despite the reality that content used as a module in this research proved valid due to learners' better performance in the post-test; but further studies are also needed in this area to control some variables which can affect learners' performance, for instance, working time, intelligence level, and students' attitude.

4. Libraries may be provided with books/ materials for the construction and validation of modules.

5. A modular approach may be used for the students of the programs other than BS Education; and to other educational levels i.e. school, college, etc.

6. Modules should be enriched and reviewed continuously to meet the requirements and capabilities of the learners and to include the latest developments considering new research in

References the relevant subjects.

Aalam, H., M. (2019). Effects of content and language integrated modular approach on English speaking proficiency in teacher education (Doctoral dissertation). Department of Education, University of Sargodha, Sargodha.

Ali, R, Ghazi, S. R., Khan, M. S., Hussain, S., Fatima, Z. T. (2010). Effectiveness of modular teaching in Biology at the secondary level. Asian Social Science, 6 (9), 49-54. ISSN 19112017 E-ISSN 1911-2025.

Ali, R. (2005). Development and effectiveness of modular teaching in Biology at the secondary level (Doctoral dissertation). University of Arid Agriculture Rawalpindi, Pakistan.

Ali, S. S. (2000). Gender and human rights in Islam and international law: Equal before Allah, unequal before man? The Hague: Boston: Kluwer Law International.

Amnesty International. (2019). Amnesty international report 2018/19: The state of the world's human rights. Peter Benenson House, 1, Easton Street, London WC1X 0DW United Kingdom. ISBN: 978-0-86210-496-2 Amnesty.org

Barnes, J., Maye, P., Alfred, R., and Hayman. (2000). Modularization of curriculum at secondary level. Kogan Page, London, UK, pp.67-98. 
Behlol, G. (2009). Development and validation of module in English at secondary level [Doctoral thesis]. International Islamic University Islamabad.

Creswell, J. W., \& Creswell, J. D. (2017). Research design: Qualitative, quantitative, and mixed methods approaches: Sage publications.

Cronbach, L. J., \& Meehl, P. E. (1951). Construct validity in psychological tests. Psychological Bulletin, 52(4), 281.

Gay, L. R., Mills, G. E., \& Airasian, P. W. (2009). Educational research: Competencies for analysis and applications. Merrill/Pearson.

Go Silk, C. J., Go Silk, B. B. and Somblingo, R. A. (2017). Modular approach in teaching problem solving: A metacognitive process. International Journal of Science and Research (IJSR), 6 (8), 2319-7064. ISSN (Online): doi: 10.21275/ART20175782

Government of Pakistan. (2009). National education policy 2009. Islamabad: Ministry of Education, Pakistan.

Government of Pakistan. (2012). 1973 Constitution of Pakistan. Islamabad, Pakistan.

Government of Pakistan. (2017). National education policy 2017-2025. Islamabad: Ministry of Federal Education and Professional Training Government of Pakistan.

Gülmez, M. (2001). Insan haklari ve demokrasi egitimi [Education for human rights and democracy] (Ankara, Turkiye ve Ortadogu Amme Idaresi Enstitüsü), No. 256.

Human Rights Commission of Pakistan. (2019). State of human rights in 2018. Aiwan-e-Jamhoor, 107 Tipu Block, New Garden Town Lahore-54600. ISBN: 978-969-8324-86-5. www.hrcpweb.org.

Human Rights Watch. (2019). World report 2019 (Events of 2018). United States of America: 350 Fifth Avenue New York, NY 10118-3299. ISBN-13: 978-1-60980-884-6. www.hrw.org.

Ibyatova, L., Oparina, K., Rakova, E. (2018). Modular approach to teaching and learning English grammar in technical universities. Proceedings of the International Scientific Conference, 1, 139-148. http://dx.doi.org/10.17770/sie2018vol1.3229

Iqbal, N. (2005). Peace and human rights education: Pakistan experience. Human Rights Education in Asian Schools, Volume VIII, Osaka, Asia-Pacific Human Rights Information Center.

Khatoon, S. (2004). Modules for the teaching of Islamiat (compulsory) at secondary school level (Doctoral dissertation). National University of Modern Languages, Islamabad.

Laroza, R. R. (2015). Validation and effectiveness of modules in personality development and public relations. International Journal of Scientific and Research Publications, 5 (9). ISSN 22503153 .

Mizrachi, A. (2010). Active-learning pedagogies as a reform initiative American Institute for Research.

Nordin, R., Shapiee, R., Suhor, S., \& Muhamad, M. M. (2012). Designing human rights subjects based on students' needs. Procedia - Social and Behavioral Sciences, 59, 715 - 722.

Nunnally, J. C., Bernstein, I. H. (1994). Psychometric Theory. Third edition. New York, McGraw Hill.

PROAP, U. (1998). Learning to live together in peace and harmony; Values education for peace, human rights, democracy, and sustainable development for Asia-Pacific Region: a UNESCOAPENIVE Sourcebook for Teacher Education and Tertiary Level Education.

Sadiq, S., Zamir, S. (2014). Effectiveness of a modular approach in teaching at the university level. Journal of Education and Practice, 5(17), 103-109. ISSN 2222-1735 (Paper) ISSN 2222288X (Online)

Sejpal, K. (2013). Modular method of teaching. International Journal for Research in Education (IJRE), 2(2), 169-171.

Shaheen, S. (2013). Impact of information and communication technology integrated modular approach on academic achievement and retention of students (Doctoral dissertation). National University of Modern Languages, Islamabad.

Tibbits, F. (2006). Universities and human rights education: Mapping growth and opportunities worldwide. Human Rights Education Associate (HREA). http://www.hrea.org/index. php?base_id=300

Yeşil, R. (2002). Okul ve ailede insan hakları ve demokrasi eğitimi. Ankara: Nobel Yayın Dağıtım. 